\title{
Improvement Of Inactivated Equine Herpes Virus-1 Vaccine Using Carbomer
}

\author{
Safaa, A. Warda ${ }^{1}$; Naglaa, I. Ali ${ }^{2}$; Fatma, F. Warda ${ }^{1}$; Ekbal, M. Farouk ${ }^{3 *}$ and Lubna, F. Farahat ${ }^{4}$ \\ ${ }^{1}$ Department of Equine Vaccines Research, Veterinary Serum and Vaccine Research Institute (VSVRI), \\ Agricultural Research Center (ARC), Egypt. \\ ${ }^{2}$ Department of Pet Animal Vaccines Research, Veterinary Serum and Vaccine Research Institute (VSVRI), \\ Agricultural Research Center (ARC), Egypt. \\ ${ }^{3}$ Department of Foot and Mouth Disease Vaccine Research, Veterinary Serum and Vaccine Research Institute \\ (VSVRI), Agricultural Research Center (ARC), Egypt. \\ ${ }^{4}$ Department of Sera and Antigens Research, Veterinary Serum and Vaccine Research Institute (VSVRI), Agricultural \\ Research Center (ARC), Egypt. \\ *Corresponding Author, Ekbal, M. Farouk, E-mail: dr.e_farouk@yahoo.com
}

\begin{abstract}
An inactivated Equine herpes virus-1 vaccine was successfully improved using carbomer as adjuvant inducing high and long immunity in vaccinated mares in comparison with the convention one adjuvanted with Al-hydra gel and saponin. Such purpose was established by using $0.5 \%$ carbomer as adjuvant to the inactivated $E H V-1$. The applied quality control tests carried out on such vaccine revealed that it is free from foreign contaminants, safe in pregnant mares and mice and potent induced high levels of specific $E H V-1$ antibodies in vaccinated Guinea pigs and mares as measure by ELISA and SNT. This immunity was sufficient to protect vaccinated horses up to 28 weeks ( 7 months) post-vaccination.
\end{abstract}

Keywords: Carbomer, ELISA, SNT, Inactivated EHV-1, Equine Virus.
Original Article:

DOI:https://dx.doi.org/10.21608/javs .2021 .140080

Received:16 November, 2020.

Accepted :27 December, 2020.

Published in January, 2021.

This is an open access article under the term of the Creative Commons Attribution 4.0 (CCBY) International License. To view a copy of this license, visit:

http://creativecommons.org/licenses/by/4.0/

J. Appl. Vet. Sci., 6(1 ): 21 - 27.

\section{INTRODUCTION}

Equine herpesvirus type 1 (EAV-1) causes abroad range of manifestations in horses, including a central nervous system disease involving the spinal cord and brain (myeloid cephalopathy), respiratory disease, abortions and perinatal death (Meaquita et al., 2017). Abortion may result from exogenous or endogenous infection, i.e., reactivation of latent virus (Allen et al., 1998).

In recent years, increased incidence of Equine herpesvirus myeloid Cephalopathy (EHM) has been observed by infection with the same virulent strains of EHHV-1 leading to inflammation of the blood vessels supply the brain and spinal cord (Henninger et al., 2007). Control of EHV-1 infection is so tricky that the symptoms may be subclinical and may be reactivated after many months or years after primary infection under stress factors (Browning et al., 1988). Vaccination is crucial to control EHV-1 infection using either live-attenuated or inactivated vaccines with the inactive one's preferable use (Mayer et al., 1978).

In inactivated vaccines, an ideal adjuvant should be safe, stable, bio gradable and ensure vaccine potency's reproducibility during manufacture (Cater and Reed, 2010). Carbomer has low reactivity, no virucidal nature and efficacy in one shot vaccination schedules; a lightly cross-linked polymer of acrylic has become widely used as an adjuvant in the veterinary field (Diamantstein et al., 1971) enhance the strength and duration of antibody responses stimulated by inactivated equine influenza vaccines as compared with vaccines of equivalent antigenic content (Wood $\boldsymbol{e t}$ al., 1983). Production of GHPV antigen inactivated adjuvanted vaccine (Jac Queline $\boldsymbol{e t}$ al., 2010) vaccine induces a robust serological response in growing gosling and breeder. Carbomer promotes an early onset of cellular immunity by facilitating the cell differentiation towards effector phenotypes and efficiently inducing native to memory transition (Mair et al., 2015). Using carbomer in animal models results 
in adjuvant system activity, including strong proinflammatory type-1 $\mathrm{T}$ cell (TH1) polarization (Schwabe et al., 1977). Carbomer adjuvanted rabies vaccines are preferable to aluminium hydroxide gel vaccine providing a high protective level in vaccinated dogs.

Saponin is extracted from Saponaria Molina can stimulate a strong immune response against exogenous antigens when used as an adjuvant (Eman et al., 2013). Tissue culture inactivated ISA-70 oil adjuvanted EHV-1 vaccine was successfully prepared from the locally isolated virus, which was entirely inactivated by $0.008 \mathrm{M}$ of binary ethyleneimine (BEI) within 24 hours at $37^{\circ} \mathrm{C}$ (Safaa et al., 2012). Vaccination was one of the best options to fight EHV-1 infection in combination with reasonable management measures. Successful vaccination against EHV-1 requires both humoral and cellular immune responses, which require the presence of a potent adjuvant to stimulate both immune responses (Paillot et al., 2008).

However, the cellular immune response is also essential in pregnant mares, positive correlation between the frequency of EHV-1 CTL (cytotoxic Tlymphocyte) and the protection against the disease (Kydd et al., 2003). This study was designed to prepare and evaluate the safety and potency of inactivated EHV-1 adjuvanted with carbomer and a mixture of saponin as vaccine adjuvants.

\section{MATERIALS AND METHODS}

\section{Equine herpes virus-1 (EHV-1)}

Locally isolated EHV-1 isolated by Hassanein et al. (2002) and adapted on Vero cell culture by Safaa (2007) identified by reference freeze-dried rabbit antiEHV-1 (kindly supplied by Dr Jennet Wellington, Research Follow Department of Biological Science, Macquarie Univ., NSW Australia) was supplied by the Department of Equine Vaccine Research (DEVR); Veterinary Serum and Vaccine Research Institute (VSVRI) and used for an inactivated vaccine.

\section{EHV-1 antiserum}

Locally prepared EHV-1 antiserum (Safaa $\boldsymbol{e t}$ al., 2005) was supplied by DEVR and used as a positive control in the serological tests.

\section{Experimental animals \\ 3.1. Mares}

Eleven health adult mares were used in the present study where 3 of them were used to test the safety, and six mares were used to test the potency of the prepared vaccine while two mares were kept without vaccinates as a test control. All mares were housed under hygienic measures receiving balanced ration and adequate water following animal ethics.

\subsection{Mice}

Three groups of pregnant Swiss Albino mice of 4-6 weeks old (4mice/ group) were used for safety testing of the prepared inactivated EHV-1 vaccine

\subsection{Guinea pigs}

Twelve seronegative Guinea pigs of about 300$400 \mathrm{gm}$ body weight were divided into three groups were the first two groups were used to assess the potency of the carbomer and Al-hydra gel with saponin adjuvanted vaccines respectively, keeping the third group without inoculation as test control and the second group was used

\section{Cell culture}

African green monkey kidney cell line (Vero) was maintained and propagated using Minimum Essential medium with Eagle's salts and used to prepare EHV-1 suspension, virus titration, and the residual viral testing inactivated virus suspension and serum neutralization test.

\section{Embryonated chicken eggs}

Specific pathogen-free Embryonated chicken eggs (SPF-ECE) of 11-13 days old were obtained from SPF eggs farm Koum Osheim, Fayoum Governorate, Egypt and used for assurance of complete virus inactivation

\section{Saponin}

Saponin was obtained from Ubichem. PLC as powder prepared as a solution of $2 \mathrm{mg} / \mathrm{ml}$ of purified saponin in distilled water with PH 7.5 and sterilized by autoclaving at $108^{\circ} \mathrm{C}$ for 15 minutes according to Hamdy (2016)

\section{Preparation of carbomer solution}

Carbomer was supplied from Lubrizol Co. as a fluffy white powder. It was dissolved in hot water to prepare $0.5 \%$ aqueous stock solutions, sterilizes by autoclaving at $121^{\circ} \mathrm{C}$ under the pressure of $1.5 \mathrm{lb} / \mathrm{inch}$ for $20 \mathrm{~min}$, then stored at $4^{\circ} \mathrm{C}$ until use (United States pharma Cofield Convention, 1990).

\section{Preparation of EHV-1 suspension}

The local EHV-1 was propagated in three successive passages in Vero cells. The virus suspension was collected and clarified by centrifugation at $3000 \mathrm{rpm}$ for 15 minutes, then titrated where the virus titer was calculated according to Reed and Muench (1938). It was recommended that the virus titer should not be less than $7 \log 10 \mathrm{TCID}_{50} / \mathrm{ml}$ for preparation of inactivated EHV-1 vaccine (OIE, 1990).

\section{Virus inactivation}

EHV-1 inactivation was carried out using $0.008 \mathrm{M}$ of Binary ethylenimine (BEI) for 24 hours according to Nehal (2006) 


\section{Detection of residual infective virus}

This step was carried out through:

10.1. Inoculation of the chorioallantoic membrane of ECE incubated at $37^{\circ} \mathrm{C}$ for five days with daily examination for detection of pock lesions, which should not be detected as recommended by Safaa and Hussein (2012).

10.2. Inoculation of Vero cells to ensure the absence of EHV-1 CPE through three blind passages according to OIE (2017)

\section{Vaccine preparation}

Two batches of inactivated EHV-1 vaccine were prepared where one of them was $20 \%$ of Al-hydra gel and the second one was mixed in equal volumes carbomer according to Naglaa et al. (2020).

\section{Quality control testing of the prepared vaccine 12.1.Sterility test}

Random samples of the prepared inactivated EHV-1 vaccine with carbomer were cultured on different media to ensure the vaccine freedom of foreign contaminants (aerobic and anaerobic bacteria, fungi and mycoplasma) according to the recommendations of OIE (2017)

\subsection{Saftey test}

\subsubsection{In mice}

This test was performed in 2 groups of pregnant mice (10 mice/group) where the first group was inoculated $\mathrm{I} / \mathrm{N}$ with $45 \mu \mathrm{l}$ of the inactivated virus/ mouse while the $2^{\text {nd }}$ group was inoculated $S / C$ with $0.3 \mathrm{ml}$ of the prepared vaccine/ mouse according to Kirisawa et al. (1995) and kept under a hygienic condition and daily observation for two weeks

\subsubsection{In mares}

Each of three mares was inoculated I/M with a dose of $2 \mathrm{ml}$ of one of the prepared vaccines/mares receiving a second dose one month later. These mares were kept under hygienic measures for two weeks.

\subsubsection{Potency test}

\subsubsection{In Guinea pigs}

This test included three groups of Guinea pigs of about 300-400 gm body weight (3 animals/group). The first group was inoculated $\mathrm{S} / \mathrm{C}$ with a $0.2 \mathrm{ml} /$ animal of the inactivated EHV-1 vaccine with rehydrated gel and saponin. The second group was inoculated in the same manner with the same dose of the prepared vaccine with carbomer. Each group received a second dose after one week. The third group was kept without vaccination as test control and serum samples were obtained from all groups on the $3^{\text {rd }}$ and $5^{\text {th }}$-week post-vaccination.

\subsubsection{In mares}

Eight healthy mares with low EHV-1 antibody titer $(\leq 4 \mathrm{NI})$ were divided into three groups as follow: Group-A of 3 mares were vaccinated I/M with a dose of $2 \mathrm{ml}$ of Al-hydra gel and saponin adjuvanted vaccine/ mare

Group-B of 3 mares were vaccinated I/M with a dose of $2 \mathrm{ml}$ of carbomer adjuvanted vaccine/ mare

Group-C of 2 mares was kept without vaccination as test control

Each of the vaccinated groups received a booster of the corresponding vaccine four weeks post the first vaccination.

Serum samples were obtained from all mares on 2-week interval up to 28 weeks post-vaccination to follow up the induced levels of EHV-1 antibodies in vaccinated mares using serum neutralization test and ELISA

\section{Serological tests}

13.1.Enzyme-linked immune sorbent assay (ELISA)

Solid-phase enzyme-linked immune sorbent assay (ELISA) was carried out on mares and Guinea pig sera as described by Sugiura et al. (1997).

\subsection{Serum neutralization test (SNT)}

SNT was carried out on vaccinated mare sera and the antibody titer was expressed as serum neutralization index (NI) according to Shanker $\boldsymbol{e t}$ al. (1989) and Hamdy (2016).

\section{RESULTS}

The applied quality control testes on the prepared vaccine revealed that it is free from foreign contaminants (aerobic and anaerobic bacteria; fungi and mycoplasma); safe inducing no abnormal local or systemic post inoculation reactions in Guinea pigs and mares and potent providing vaccinated animals with good levels of specific EHV-1 antibodies as shown in table (1).

Table 1: Quality of the prepared inactivated EHV-1 vaccine adjuvanted with carbomer

\begin{tabular}{|c|c|c|c|c|}
\hline \multicolumn{2}{|c|}{ Applied tests } & \\
\hline \multirow{2}{*}{$\begin{array}{c}\text { Virus titer } \\
\text { before }\end{array}$} & Sterility & \multicolumn{2}{|c|}{ Safety } & \multicolumn{2}{|c|}{ Potency } & Result \\
\cline { 3 - 4 } inactivation & In mice & In mares & $\begin{array}{c}\text { In Guinea } \\
\text { pigs }\end{array}$ & In mares \\
\hline $\begin{array}{c}8.5 \log 10 \\
\mathrm{TCID}_{50} / \mathrm{ml}\end{array}$ & $\begin{array}{c}\text { Free from } \\
\text { foreign } \\
\text { contaminants }\end{array}$ & $\begin{array}{c}\text { Safe inducing no } \\
\text { abnormal signs in } \\
\text { both animals }\end{array}$ & $\begin{array}{c}\text { Potent inducing high } \\
\text { specific EHV-1 } \\
\text { antibodies }\end{array}$ & Valid \\
\hline
\end{tabular}


Application of indirect ELISA on serum samples of vaccinated Guinea pigs showed that these animals exhibited antibody titers 400 and 490 by the $3^{\text {rd }}$ week post vaccination in those vaccinated with the alhydra gel vaccine and those vaccinated with the carbomer vaccine reached to titers of 940 and 1019 by the $5^{\text {th }}$ week post vaccination respectively (table 2).

Table 2: Mean EHV-1 ELISA titer in vaccinated Guinea pigs

\begin{tabular}{|c|c|c|c|}
\hline \multirow{2}{*}{$\begin{array}{l}\text { Periods post- } \\
\text { vaccination }\end{array}$} & \multicolumn{3}{|c|}{ Mean EHV-1 ELISA titer $(\log 10)$ in Guinea pigs vaccinated with } \\
\hline & $\begin{array}{c}\text { EHV-1 with Al-hydra gel } \\
\text { and saponin }\end{array}$ & $\begin{array}{l}\text { EHV-1 with } \\
\text { carbomer }\end{array}$ & Unvaccinated control \\
\hline 0 time & 0 & 0 & 0 \\
\hline 3 weeks & 400 & 490 & 0 \\
\hline 5weeks & 940 & 1019 & 0 \\
\hline
\end{tabular}

Regarding vaccination of mares tables ( 3 and 4 ) showed that the inactivated EHV-1 vaccine adjuvanted with carbomer induced higher ELISA titer (1480) by the $6^{\text {th }}$ week post vaccination while the gel vaccine showed ELISA titer (1360) on the same period with SNI 2.0 and 1.9 by the 2 vaccines respectively. Peak titers (1690 and 1595 by ELISA and 3.5 and 3.2 SNI respectively by the $10^{\text {th }}$ week recording their lowest levels (803 and 770 by ELISA and 1.8 and 1.3 SNI respectively by the $28^{\text {th }}$ week.

Table 3: Mean EHV-1 ELISA titer in vaccinated mares

\begin{tabular}{|c|c|c|c|}
\hline \multirow{2}{*}{$\begin{array}{c}\text { Weeks post- } \\
\text { vaccination }\end{array}$} & \multicolumn{3}{|c|}{ Mean EHV-1 ELISA titers (log10) induced by } \\
\cline { 2 - 4 } & Aduvanted vaccine & $\begin{array}{c}\text { Adjuvanted vaccine with Al- } \\
\text { hydra gel and saponin }\end{array}$ & $\begin{array}{c}\text { Unvaccinated } \\
\text { control mares }\end{array}$ \\
\hline 2 & 605 & 530 & 100 \\
\hline 4 & 550 & 400 & 93 \\
\hline Bootstring) & 1480 & 1360 & 95 \\
\hline 6 & 1605 & 1590 & 105 \\
\hline 8 & 1690 & 1595 & 95 \\
\hline 10 & 1620 & 1980 & 110 \\
\hline 12 & 1508 & 1230 & 100 \\
\hline 14 & 1390 & 1120 & 95 \\
\hline 16 & 1120 & 1001 & 150 \\
\hline 20 & 990 & 880 & 95 \\
\hline 24 & 803 & 770 & 95 \\
\hline 28 & & & \\
\hline
\end{tabular}

Table 4: Mean EHV-1 serum neutralizing indices in vaccinated mares

\begin{tabular}{|c|c|c|c|}
\hline \multirow{2}{*}{$\begin{array}{c}\text { Weeks post- } \\
\text { vaccination }\end{array}$} & $\begin{array}{c}\text { Adjuvanted vaccine } \\
\text { with carbomer }\end{array}$ & $\begin{array}{c}\text { Adjuvanted vaccine with Al- } \\
\text { hydra gel and saponin }\end{array}$ & $\begin{array}{c}\text { Unvaccinated } \\
\text { control mare }\end{array}$ \\
\hline 0 time & 0.4 & 0.3 & 0.2 \\
\hline 2 & 0.7 & 0.6 & 0.3 \\
\hline 4 & 0.8 & 0.6 & 0.3 \\
(Bootstring) & 2.0 & 1.9 & 0.3 \\
\hline 6 & 3.0 & 2.8 & 0.5 \\
\hline 8 & 3.5 & 3.2 & 0.3 \\
\hline 10 & 3.5 & 2.8 & 0.3 \\
\hline 12 & 3.3 & 2.5 & 0.4 \\
\hline 14 & 3.0 & 2.0 & 0.4 \\
\hline 16 & 2.8 & 1.5 & 0.5 \\
\hline 20 & 2.5 & 1.5 & 0.5 \\
\hline 24 & 1.8 & 1.3 & 0.3 \\
\hline 28 & & & \\
\hline
\end{tabular}




\section{DISCUSSION}

The present study was performed for the preparation and evaluation of inactivated EHV-1 vaccine adjuvanted with carbomer. The present obtained results showed that the prepared inactivated EHV-1 adjuvanted with carbomer is free from foreign contaminates; safe in mice and mares and potent in Guinea pigs and mares (table-1), coming in agreement with the directions of OIE (2017). The obtained virus titer after three blind passages in Vero cells was found to be $8.5 \log 10 \mathrm{TCID}_{50} / \mathrm{ml}$ recording a higher value than that recommended by Hamdy (2016) and OIE (2019). They concluded that EHV-1 titer should not be less than $7 \log 10 \mathrm{TCID}_{50} / \mathrm{ml}$ before virus inactivation. Such a high virus titer ensures the production of a potent inactivated vaccine.

Insurance of the safety of the presently prepared vaccine showed that all vaccinated horses showed average body temperature and no local or systemic postvaccinal reactions following neither the first of the second dose and there were no abortion in pregnant mares and mice, coming in agreement with the recommendations of OIE (2019).

The preliminary study of the prepared vaccine immune response was conducted in Guinea pigs. Table (2) showed detectable EHV-1 antibodies with mean ELISA titer 490 and 400 on the third-week postvaccination with carbomer rehydra gel vaccines, respectively. These titers increased to 1019 and 940 by the two vaccines respectively by the second-week post the booster dose ( 5 weeks post the first dose). These findings coincidence with those of Guo et al. (1989) and Dalia (2017).

Table (3) demonstrates that the mean EHV-1 ELISA antibody titers were 605 and 530 induced in vaccinated horses with carbomer and_-rehydra gel with saponin adjuvanted vaccines respectively on the $2^{\text {nd }}$ week post administration of the $1^{\text {st }}$ dose and increases to 1480 and 1360 respectively on the $2^{\text {nd }}$-week post bootstring recorded peak titers (1690 and 1595 by the two vaccines respectively) on the $10^{\text {th }}$-week post the first vaccination then declined till the $28^{\text {th }}$ week with mean values 803 and 770 respectively. These results correlated with those of Kydd et al. (2006) and Nashwa et al. (2016), who stated that vaccinated horses became protected against EHV-1 infection to 36 months with a decline in abortion.

Table (4) represented the results of SNT expressed as NI, which was detectable two weeks postvaccination by mean values 0.7 and 0.6 induced by carbomer and rehydra gel with saponin vaccines, respectively. After boosting, there was a gradual increase significantly in NI with mean values 3.5 and
2.8 by the $12^{\text {th }}$-week post-vaccination, then began to decline to reach 1.8 and 1.3 by the $28^{\text {th }}$ week. These results agree with those of Senthil et al. (2014), Shankar et al. (1989) and Hamdy et al. (2016) who reported that NI of EHV-1 was ranged between 1.5-3.5 could resist the challenge of EHV-1 infection. Also, these results agree with Bannai et al. (2014) and OIE (2019), who found that ELISA antibodies begin to increase by day 14 post-vaccination then reached their peak at two months with a 4-fold increase indicated an excellent immune response.

The obtained data indicate that carbomer has a potential effect eliciting higher levels of humoral antibodies with a longer duration of immunity than the conventional Al-hydra gel adjuvant.

\section{CONCLUSION}

Depending on the present obtained results, it could be concluded that the prepared EHV-1 inactivated vaccine adjuvanted with carbomer is safe and more potent than that prepared with Al-hydra gel.

\section{Declaration of Competing interest}

On behalf of all authors, I hereby declare that no conflict of interest may interfere with the publication of the manuscript.

\section{REFERENCES}

ALLEN, G. P.; KYDD, J. H.; SLATER, J. D. AND SMITH, K. C. 1998. Advances in understanding of the pathogenesis, epidemiology and immunological control of equine herpesvirus abortion. In: Equine Infectious Diseases,

ANDERSON, E. C.; MASTER, R. C. AND MOWAT, G. N. 1971. Immune response of pigs of inactivated footand-mouth disease vaccines. Response to DEAEDextran and saponin adjuvated vaccines \& quote; Res. Vet. Sci.; (12): 351-357

BERNHARDT, D. 1993. In vitro diagnosis of EHV (EHV-1 and EHV-4) Tieroriztliche Umschau, 48(2): 67-68, 70-72.

DALIA NASER 2017. Study the effect of different adjuvants on inactivated equine herpes virus -1 vaccine. M.Sc. Virology, Fac. Science, Al-Azhar.Uni.

DIAMANTSTEIN T, WAGNER B, BEYSE I, ODENWALD MV, AND SCHULZ G. I. 1971. Stimulation of humoral antibody formation by polyanions. The effect of polyacrylic acid on the primary immune response in mice immunized with sheep red blood cells. Eur J Immunol, 1; 335-340

EMAN, M. EBEID; NASHWA, K. MADKOUR; NEHAL,S. SALEH; SAFAA, A.WARDA; ESKANDER,N.B; MAGDA,A. KALAD ANDSOLIMAN, I.M.A.2013. Effect of Quillaja saponaria Molina extract on Equine influenza and Equine Herpes virus -1. Zag. Vet.J.Vol. 41 No. 4 (2013) pp 158-165. 
GUO, P., GOEBEL, S., DAVIS, S., PERKUS, M. E., LANGUET, ,DESMET\&\#39;RAE, P., ALLEN, G. P. AND PAOLETRT, E. 1989. Expression in recombinant vaccinia virus of the equine herpesvirus 1 gene encoding glycoprotein gpl3 and protection of immunized animals. Journal of Virology 63, 41894198.

HAMDY ABD EL-RAHMAN, 2016. Preparation of inactivated EHV-1 with different adjuvants, Ph. D. Thesis; Immunology, Fac. Vet. Med. Alexandria Univ.

HASSANEIN, MM; MAYSA, H.; EL-BAGOURY, F.; MAGDA, A.K.; EL-KABBANY, M.M.A. AND DAOUD, M.A. 2002. Trials for isolation and identification of equine herpesvirus abortion in Egypt. Vet. Med. J., Giza, 50 (4): 977-986.

HENNINGER, R. W.; REED, S. M. AND SAVILLE, W. J.(2007. Outbreak of neurologic disease caused by equine herpesvirus-1 at a university equestrian center. J Vet Intern; (21):157-165.

JACQUELINE GELFI, MICHAEL PAPPALARDO, CARINE CLAVERYS, BRIGITTE PERALTA AND JEAN-LUC GUERIN (2010): Safety and efficacy of an inactivated Carbopol adjuvanted goose hemorrhagic polyomavirus vaccine for domestic geese. Avian Pathology, 39 (2), 111-116.

KIRISAWA, R.; TERADA, M.; SEKIYA, N; KAWAKAMI, Y. AND IWAI, H. 1995. Growth and potentials of attenuated strains of EHV-1 in lungs of mice. J.Vet. Med. Series b, 42 (7): 391-39.

KYDD, J.H.; WATTRANG E. AND HANNANT D. 2003. Pre-infection frequencies of equine herpesvirus-1 specific cytotoxic $\mathrm{T}$ lymphocytes correlate with protection against abortion following experimental infection of pregnant mares; Vet. Immunopathol. 96: 207- 217.

KYDD, J.H.; DAVIS-POYNTER NJ.; BIRCH J.; HANNANT D.; MINKE J.; AUDONNET JC.; ANTEZAK DF. AND ELLIS SA. 2006. A molecular approach to the identification of cytotoxic T-lymphocyte epitopes within equine herpesvirus-1; J. Gen. Virol. 87: 2507-2515

LARGHI, O.P. AND A.E. NEBEL, 1980. Rabies virus inactivation by binary ethylenimine: New method for inactivated vaccine production. J. Clin. Microbiol, vol.2, pp.120-122.

MAIR K H, KOINIG H, GERNER W, HOHNE A, BRETTHAUER J AND KROLL JJ. 2015. Carbopol improves the early cellular immune responses induced by the modified-live vaccine. Ingelvac PRRS((R)) MLV. Vet. Microbiol, 176:3527.

MAYR A., THEIN, P. \& AMP; SCHEID, N. 1978. Immunization experiments with inactivated EHV-1. In proceeding 4 th Int. Conf., Equine infect. Dis., Lyon edited by Bryans, J.T.and Gerber Vet. Pub. Inc. Princeton, New Jersey, P.P 57-67.

MESQUITA A L P., ANDRESSA FERRARI ARE'VALOA, DENNIS A. ZANATTOA, SAMANTHA IVE MIYASHIROA, ELENICE MARIA SEQUETIN CUNHAB , MARIA DO CARMO CUSTO'DIO DE SOUZAB, ELIANA MONTEFORTE CASSARO VILLALOBSB,
CLA'UDIA MADALENA CABRERA MORIA, PAULO CE'SAR MAIORKAA, ENIO MORIA, C. 2017. Equine herpesvirus type 1 induces both neurological and respiratory disease in Syrian hamsters. Vet. Microbiol., 203,117-124.

NASHWA KM.; EMAN ME.; NEHAL SS; FATMA FY.; EL-KABBANY MMA AND SOLIMAN I.M.A. 2016. Duration of immunity induced by combined vaccine against equine influenza and equine herpesvirus-1, VMJG, 62: 1110-1423.

NEHAL, S. SALEH,,2006. Preliminary trials for production of equine viral abortion inactivated vaccine. Ph. D. Thesis, virology, Benha Univ.

NAGLAA I. ALY, OMAIMA A. EL-SHAMANDY, SHENDY, M.B; FATMA F. WARDA; AND EKBAL, M. FAROUK, 2020. Efficacy of using Carbopol as an adjuvant for Tissue Culture Inactivated Rabies Vaccine. Journal of Applied Veterinary Sciences, 5(3): 103 - 107.

OIE. 1990. Equine rhinopneumonites. Manual of standards diagnostic tests and vaccines. 2nd edition chapter 2-59 pp 1-6.

OIE .201. Equine rhinopneumonites. Manual of standards diagnostic tests and vaccines. 8th edition chapter 2-59 pp 1-13.

OIE. 2019. Equine rhinopneumonites . Manual of standards diagnostic tests and vaccines. Chapter 12-8.

PAILlOT, R.; CASE, R.; ROSS, J.; NEWTON, R. AND NUGENT, J. 2008. Equine Herpes Virus-1: Virus, Immunity and Vaccines. Veterinary Science Journal; 2: 68-91.

POUWELS, H. G. W., BSC, VAN DE ZANDE, S. M. A., DVM, PH,.D. DIP. ECPVS, HORSPOOL, L. J. I., BVMS, PH.D., DIP. ECVPT, MRCVS, AND HOEIJMAKERS, M. J. H., MSC. 2014. Efficacy of a non-updated, Matrix-C-based equine influenza subunit-tetanus vaccine following Florida sublineage clade 2 challenge. Vet Rec. Jun; 174(25): 633.

REED, L.T AND MUNECH, H. 1938. A simple method of estimating 50\% end points. Am., J. Hyg., 27: 493.

SAFAA, A. WARDA; TARADI, A. SAID AND DAOUD, A.M. 2005. Trials for preparation and evaluation of locally prepared polyclonal immune serum against EHV. $4^{\text {th }}$ Int. Sci. Conf. Mansoura Univ., 477-486.

SAFAA, A. W. 2007. Adaptation of locally isolated EHV-1 on different cell line. 5th Int. Sci. Conf. Beni Suef Vet. Med.: 52-60.

SAFAA A. WARDA AND HUSSIN, M. G. 2012. Immune response of horses vaccinated with tissue culture inactivated EHV - 1 oil Montanide ISA70 adjuvanted vaccine. Egypt J. Agric, Res; 90(3), 1309 - 1321.

SHANKER, H. AND YADAV, M. P. 1986. Occurrence of paralytic syndrome in equines due to equine Herpes virus - 1 Rev. Sci, Tech, Off. Int. Epiz., 5 (1): 15-21

SCHWABE, C.W., RIEMANN, H. AND FRANTI, F. 1977. Epidemiology in veterinary practice. $1^{\text {st }}$ Ed. Lee and Febiger, PhiladelphiaSuGiura, T.; Kondo, T.; Matsumura, T.; Imagawa, H;. Kamada, M. and Ihara, T. (1997): Evaluation of enzyme-linked immunosorbent assay for titration of antibodies to EHV-1. J. Equine Sci,. 3 (8): 57-61. 
SLATER, I.D.; GIBSON J.S. AND FIELD, H. J. 1993. Pathogenicity of thymidine kinase-deficient mutant of EHV-1 in mice and specific pathogen-free foals, J. Gen Virol., 74(5): 819-828.

SUGIURA T.; KONDO T.; MATSUMURA T.; IMAGAWA H.; KAMADA M. AND IHARA T. 1997. Evaluation of enzyme-linked immunosorbent assay for titration of antibodies to EHV-1, J. Equine Sci. 8 (3): 57-61.

United States Pharmacopeial Convention (1990): Carbomer. Inc. Rockville, Maryland, 1911.

WOOD JM.; MUMFORD J.; FOLKERS O.; SEOTT AM, SCHILD GC. 1983. Studies with inactivated equine influenza vaccine. 1. Serological responses of ponies to graded doses of vaccine. J Hyg. 1983: 90: 371-84.

How to cite this article:

Safaa, A. Warda; Naglaa, I. Ali; Fatma, F. Warda; Ekbal, M. Farouk and Lubna, F. Farahat, 2021. Improvement Of Inactivated Equine Herpes Virus-1 Vaccine Using Carbomer. Journal of Applied Veterinary Sciences, 6 (1): $21-27$.

DOI: https://dx.doi.org/10.21608/javs.2021.140080 